\title{
Extending the Energy efficiency gap
}

\author{
Sandra Backlund, Patrik Thollander, Mikael Ottosson and Jenny Palm
}

\section{Linköping University Post Print}

N.B.: When citing this work, cite the original article.

Original Publication:

Sandra Backlund, Patrik Thollander, Mikael Ottosson and Jenny Palm, Extending the Energy efficiency gap, 2012, Energy Policy, (51), 392-396.

http://dx.doi.org/10.1016/j.enpol.2012.08.042

Copyright: Elsevier

http://www.elsevier.com/

Postprint available at: Linköping University Electronic Press

http://urn.kb.se/resolve?urn=urn:nbn:se:liu:diva-86546 


\title{
Extending the energy efficiency gap
}

\author{
Sandra Backlund $^{\mathrm{a} *}$, Patrik Thollander ${ }^{\mathrm{a}}$, Jenny Palm ${ }^{\mathrm{b}}$, Mikael Ottosson ${ }^{\mathrm{c}}$ \\ ${ }^{a}$ Department of Management and Engineering, Division of Energy Systems,
} Linköping University, SE-581 83 Linköping, Sweden

${ }^{\mathrm{b}}$ Department of Thematic Studies, Technology and Social Change, Linköping University, SE-581 83 Linköping, Sweden

${ }^{\mathrm{c}}$ Department of Management and Engineering, Division of Business Administration, Linköping University, SE-581 83 Linköping, Sweden

*Tel: +461328282767

\begin{abstract}
In order to reach the EU: s 20-20-20 primary energy savings target, energy efficiency needs to increase. Previous research on energy use and energy efficiency has focused mainly on the diffusion of energy efficient technologies. The discrepancy between optimal and actual implementation of energy efficient technologies has been illustrated in numerous articles and is often referred to as the energy efficiency gap. However, efficient technologies are not the only ways to increase energy efficiency. Empirical studies have found that a cost-effective way to improve energy efficiency is to combine investments in energy-efficient technologies with continuous energy management practices. By including energy management into an estimated energy efficiency potential this paper introduces
\end{abstract}


an extended energy efficiency gap, mainly in manufacturing industries and the commercial sector. The inclusion of energy management components in future energy policy will play an important role if the energy savings targets for 2020, and later 2050, are to be met in the EU.

Keywords: Market barriers, Energy management, Energy efficiency gap, The extended energy efficiency gap

\section{Introduction}

In 2006, the European Union (EU) adopted the Energy Services Directive (ESD), which target is to reduce energy use in the EU by $9 \%$ by 2016 in the non-trading parts of the economy. In addition, the EU's new 2020 primary energy target aims to improve energy efficiency in all sectors of the economy by $20 \%$ by 2020 relative to the 2005 level. This article mainly concerns energy efficiency in manufacturing industries and the commercial sector. Both the ESD and the 2020 primary energy target emphasize potential energy savings in the industrial sector, particularly in industrial small and medium-sized enterprises (SMEs). In the 20-20-20 strategy, the European Commission (EC) has estimated the technical energy-saving potentials in various sectors, estimating them to be $25 \%$ in manufacturing, $30 \%$ in commercial buildings, and $26 \%$ in private households. This calls for implementation rates for energy saving measures of $77 \%$ (commercial sector) and $80 \%$ (manufacturing industry). Scientific evidence of such high implementation rates is scarce in the building and industry sectors (Thollander et al., 2012).

This article outlines how energy management practices can increase both the energy efficiency potential and the deployment level of energy policy programs. The academic literature and policy documents have so far focused mainly on improved technical energy efficiency and the potential for such, while theoretical contributions examining the role of energy management practices at site have been scarce. The paper begins by briefly presenting the energy efficiency gap; it continues by 
examining how this gap is related to energy policy, barriers to energy efficiency, and energy management, and ends by presenting what the authors refer to as the extended energy efficiency gap. In this paper, we argue that the potential for energy savings and improved energy efficiency is greater than what is commonly claimed, if the potential embedded in energy management practices in addition are included.

\section{The energy efficiency gap}

One key factor stressed in the scientific literature (e.g., Hahn and Stavins, 1992; Sorrell et al., 2004) and in EU policy documents on energy efficiency is cost effectiveness. However, both policy documents and the academic literature state that cost-effective energy measures are not always implemented. This discrepancy between optimal and actual implementation is often referred to as the energy efficiency gap, which has been illustrated and examined in multiple academic articles (e.g., York et al., 1978; Blumstein et al., 1980; Stern and Aronsson, 1984; Hirst and Brown, 1990; Gruber and Brand, 1991; Stern, 1992; DeCanio, 1993; Jaffe and Stavins, 1994; Sanstad and Howarth, 1994; Weber, 1997; Ostertag, 1999; Sorrell et al., 2000; Brown, 2001; de Groot et al., 2001; Schleich, 2004; Sorrell et al., 2004; Rohdin and Thollander, 2006, Thollander et al., 2007; Rohdin et al., 2007; Thollander and Ottosson, 2008; Schleich and Gruber, 2008; Sardianou, 2008; Hasanbeigi et al., 2010; Fleiter et al., 2011; Trianni and Cagno, 2011; Chai and Yeo, 2012). One of the most cited of these articles is by Jaffe and Stavins (1994), who explain the gap and how its extent differs depending on the definition of energy efficiency potential used and the perspective addressed. Three perspectives on energy efficiency potential are discussed: the hypothetical potential, the technologist's economic potential, and the economist's economic potential. The hypothetical potential is the total energy efficiency potential if all technologically available measures are implemented. The difference between the technologist's and the economist's potential lays in their views of market barriers (Jaffe and Stavins, 1994). 
The energy efficiency gap between cost-effective energy efficiency measures and the measures actually implemented is explained by market failures and barriers to energy efficiency. The concept of market failures, the narrower of the terms, is derived from neo-classical economics. A market failure is any deviation from the assumptions of a perfect market. The term market barrier is broader and includes economic, organizational, and behavioral obstacles. For a more thorough description, see Sorrell et al. (2004).

According to economics, correcting market failures is one of the main justifications of policy measures (DeCanio, 1998). The difference between the economists' and the technologists' potential is that the economist argues that, providing there are no market failures, profit-maximizing actors will behave efficiently. However, this is dependent on whether: all external costs are included in the energy price, the market contains homogenous products, there are barriers to entering or exiting the market, an infinite number of actors and sellers exists, information is perfect, factor mobility is perfect, and there are constant returns to scale and costless transactions. A perfect market will achieve the social optimum, which Jaffe and Stavins (1994) refer to as the narrow social optimum.

Energy demand is relatively inelastic, since energy is a necessity good for most industrial sectors and households (Bertoldi, 2001; Thollander et al., 2007). The demand for energy efficiency in a perfect market depends on the marginal cost of energy and of energy efficiency measures. The technologist's potential, according to Jaffe and Stavins (1994), is higher than the economist's potential, since it argues that discount rates for investments in energy efficiency would be lower if barriers were adjusted for.

\subsection{The energy efficiency gap related to energy policies}


The potentials estimated by the EC can be seen as estimates of the energy efficiency gap in various sectors; one can conclude from the policy documents (e.g., EC, 2006) that the EC shares the technologist's view of energy efficiency potential. Not only are market failures to be overcome according to the ESD, but market barriers as well. If the objective was to make the energy market work more efficiently, then the focus would only be on eliminating existing market failures. The market would then work efficiently, assuming that all external costs are internalized in the energy price. Instead, the ESD argues that a socially optimal level of energy efficiency only can be achieved by means of stringent policy measures addressing both market failures and market barriers. The ESD highlights the importance of member states' providing information on energy efficiency, fostering energy market transparency, and creating incentives and market instruments promoting increased energy efficiency.

Suggested measures for overcoming energy efficiency barriers include white certificates, Voluntary Agreement (VA) or Long Term Agreement (LTA) programs, financial aid programs (subventions), and promoting energy service markets by providing model contracts and certifications (EC, 2006). These suggestions are often based on direct or indirect subsidies. By providing public funds to support energy efficiency measures and programs, the goal is to make improved energy efficiency less expensive and thereby increase the demand for energy-efficient technology. An alternative way to increase the demand for energy efficiency measures would be to increase the price of energy. However, increasing energy prices locally, can lead to energy intensive activities moving to areas where energy prices are lower. Similar correlations have been illustrated for greenhouse gas emissions and the phenomena is referred to as carbon leakage. (Eichner and Pethig 2011; Bakiber 2005)

\section{The extended energy efficiency gap}




\subsection{Barriers to energy efficiency}

As stated previously many empirical studies of barriers to energy efficiency have examined why energy efficiency measures are not being implemented. Barriers related to access to capital have been stressed as important: technological diffusion often requires investment, and energy efficiency has been proven to rank mainly on investments and technological low on priority lists (DeCanio, 1998). Bounded rationality is a barrier to the diffusion of energy-efficient technology; investment decisions are not always based on accurate information, but, because of time constraints and lack of easily accessible information, on rules of thumb and traditions. If this is so, then it is reasonable to assume that the tradition of estimates and rules of thumb trickles down from decision making to the actual management of technological equipment.

\subsection{Energy management}

The term energy management has been used differently in academic literature, there is no cohesive definition. What many descriptions of energy management have in common is that they mainly focus on implementation of energy efficient technologies and replacing inefficient equipment. However, energy management also includes care and maintenance of technology to preserve an efficient operation. It requires continues work and improvements. (Gordic et al. 2010)

What successful energy management means depends on the organization. For firms it depends on the size and type of industry (Mckeiver and Gadenne 2005). However, many descriptions of energy management contain similarities. Abdelaziz et al. (2011) claim that successful energy management consists of three parts: energy auditing to gain knowledge about energy flows, courses and training to increase and maintain awareness and housekeeping that includes keeping up the operations. John (2004) describes similar recommendation for strategic energy management practices: capture data, set efficiency goals, and communicate on-going energy performance to stakeholders in an 
organization. Sword et al. (2008) describe it as a combination of engineering, management and housekeeping. They also underline the importance of continuity: data collection, analysis, reporting and action.

Energy management practices aim at improving energy efficiency. Data gathering and analysis help facilitate investments in technology but by working continuously it can also detect inefficiencies and mal-functioning equipment, optimize the energy system and evaluate the technologies performance.

Though energy management practices has been scarcely studied (Caffal, 1995; Christofferson et al., 2006; Thollander and Ottosson, 2010), its importance has been demonstrated in several empirical studies of the manufacturing sector (Caffal, 1995; Christofferson, 2006; Thollander and Ottosson, 2010). Studies of the driving forces for energy efficiency in manufacturing industry demonstrate that long-term energy strategies and committed and skilled energy managers are important factors spurring energy efficiency in industrial firms. In fact, these studies indicate that such factors are ranked on parity with the driver cost reductions resulting from lower energy use (Thollander and Ottosson, 2008; Thollander et al., 2009). The adoption levels of energy management are low, even in energy-intensive industry; for example, a study of energy management practices in Swedish energyintensive industries revealed that only $25-40 \%$ of the companies could be described as successful when it came to energy management (Thollander and Ottosson, 2010).

Research into energy use and efficiency has focused mainly on the diffusion of efficient technologies. Energy management does not demand large capital investments or increased operating costs: even relatively low-cost measures such as staff training and altering day-to-day practices have been demonstrated to have large overall effects (Bernstein et al., 2007). A study of energy management practices in Danish firms found that only 3-14\% of the studied firms practiced energy management. Energy management may consist of many measures, but the Danish study set up a list of minimum requirements: firms had to have an energy policy, have set quantitative energy-saving 
goals (or objectives concerning the implementation of specific energy-saving projects), and have implemented energy-saving projects originating from energy management (Christoffersen et al., 2006).

A study of energy management in Swedish energy-intensive firms (Thollander and Ottosson, 2010) also identified considerable potential for energy management practices. In addition to the Danish requirements, the study focused on energy cost allocation and sub-metering. In a situation in which energy costs are dealt with centrally and allocated per square meter, split incentives is a problem. If energy costs are not allocated to specific departments or divisions, individual departments and divisions will lack incentives to work actively on energy management. The study found that a large majority of studied firms lacked sub-metering and did not allocate energy costs per division. (Thollander and Ottosson, 2010).

\subsection{The extended energy efficiency gap}

While studies of barriers to energy efficiency and the energy efficiency gap have largely focused on the diffusion of energy-efficient technologies, it is argued that the overall potential for energy efficiency - the extended energy efficiency potential — would in fact be higher if successful energy management practices were considered. Investments in technology and upgrading equipment generate improved efficiencies, but without maintenance and continuous monitoring the total efficiency potential will not be attained. Energy management practices can facilitate investments in energy efficiency by providing information about energy flows and potential savings, but it also contains a dimension that is less capital intensive and rather requires knowledge, attention and awareness. Fig. 1 expresses the improved energy efficiency potential if energy management practices were adopted. 


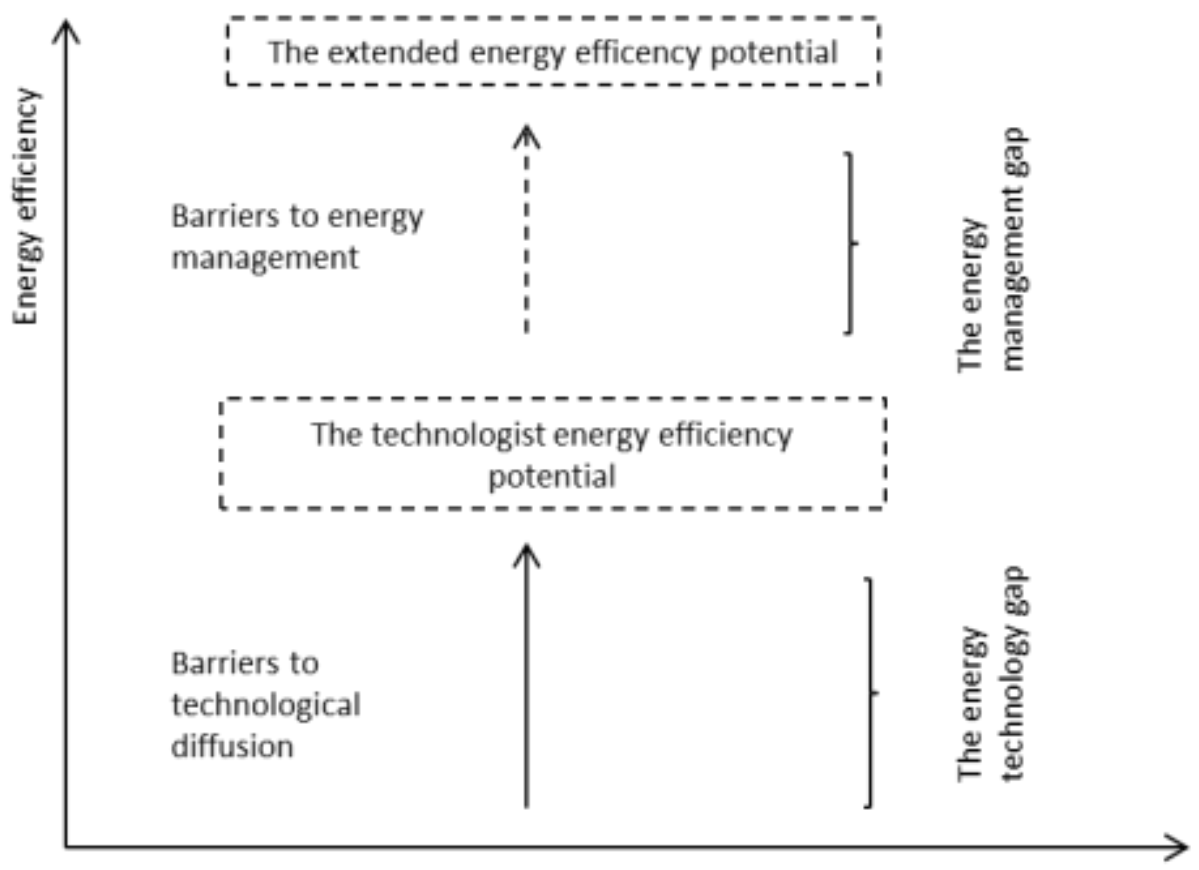

Fig. 1. The extended energy efficiency gap: the energy efficiency potential level is increased if energy management practices are also included.

It is important to note that the potential for improving energy efficiency through adopting energy management practices differs greatly depending on the size of the firm, production type (e.g., batch or continuous flow), energy intensity (e.g., related to the amount of energy used by production versus support processes), degree of production automation, previous emphasis on energy efficiency in the organization, etc. For example, a heavily automated production facility in an energy-intensive process industry using a lot of energy in its production process may have a lower extended energy efficiency potential than the technical energy efficiency potential if energy management practices are adopted. In contrast, the extended energy efficiency potential in a non-energy-intensive facility using considerable energy in the support process may be twice as high as the stated technical energy efficiency potential of $25 \%$, according to the EC (2006). The existence of this high extended energy efficiency potential is supported by Waide and Brunner (2011), who stated that, while the energy efficiency potential of an electric motor may be fairly small, the efficiency potential of the total 
motor system can be improved greatly by management practices (Waide and Brunner, 2011). Studies of the potential for improved energy efficiency normally emphasize the actual technology, and not the technology in its context or system (see, e.g., EC, 2006). In summary, the extended energy efficiency potential, including energy management practices (and thus the technology related to its context or system), is greater than the technical potential but may vary widely between industries and companies.

In a novel attempt to estimate the magnitude of the extended energy efficiency gap, Backlund et al (2012) found that when Swedish manufacturing firms, energy were asked to estimate the potential for improving energy efficiency the importance of management and technological investments were ranked similarly. The potential for improving energy efficiency through more efficient technologies was evaluated to be $13 \%$ and $5 \%$ of the current energy use, respectively among the studied nonenergy intensive and energy-intensive Swedish manufacturing firms. The estimated potential for improving energy efficiency through increased energy management practices was found to be $20 \%$ and $13 \%$ respectively among the studied non-energy intensive and energy-intensive Swedish manufacturing firms (Backlund et al., 2012).

The extended energy efficiency gap has implications for energy policies for industry. The existence of the extended energy efficiency gap implies that the potential for energy policies which includes energy management components like VAs or LTAs are in fact higher than if solely technology is considered. One way for policy makers to relate to the extended energy efficiency gap is to further highlight energy information programs like energy audits in combination with VAs or LTAs.

\section{Conclusions}


To achieve ambitious energy conservation targets, extensive measures are needed in all sectors of the economy. Wesserlink et al. (2010) found that the effects of energy policies need to be tripled if the EU's primary energy target for 2020 is to be achieved.

The importance of promoting investments in more energy-efficient technologies in order to reach the ambitious energy efficiency targets cannot be overstated. However, energy management practices must also be considered when discussing how to form future industrial energy systems. Discussions of energy efficiency potential and its level of deployment have so far largely focused on technology. By including energy management practices when defining energy efficiency potential, this paper demonstrates that the energy efficiency potential is greater than if only technology is included in the definition. The authors' refer to this as the extended energy efficiency potential.

In conclusion, cost-effective ways to improve energy efficiency in the economy is to combine investments in energy-efficient technologies with the promotion of good energy management practices. The authors argue that the inclusion of energy management components in future energy policy will play an important role if the targets for 2020, and later 2050, are to be met in the EU. One way for policy makers to address this is to further highlight the importance of energy audits in combination with voluntary agreement or long term agreement programs. Further research is suggested quantifying the extent of the extended energy efficiency gap and how this can be addressed through policy instruments.

\section{Acknowledgments}

The work has been carried out under the auspices of the Energy System Programme, funded by the Swedish Energy Agency. 


\section{References}

Abdelaziz E.A., Saidur R., Mekhilef S., 2011, A review on energy saving strategies in industrial sector, Renewable and Sustainable Energy Reviews 15 : 150-68

Babiker, M.H, 2005, Climate change policy, Market structure, and carbon leakage, Journal of International Economics 65: 421-45

Backlund, S., Broberg, S., Ottosson, M., Thollander, P., 2012. Energy efficiency potentials and energy management practices in Swedish firms. In ECEEE 2012 Industry Summer Study.

Bernstein, L., J. Roy, K. C. Delhotal, J. Harnisch, R. Matsuhashi, L. Price, K. Tanaka, E. Worrell, F. Yamba, Z. Fengqi, 2007: Industry. In Climate Change 2007: Mitigation. Contribution of Working Group III to the Fourth Assessment Report of the Intergovernmental Panel on Climate Change [B. Metz, O.R. Davidson, P.R. Bosch, R. Dave, L.A. Meyer (eds)], Cambridge University Press, Cambridge, United Kingdom and New York, NY, USA.

Bertoldi P., 2001, Effective policies and measures in energy efficiency in end-use equipment and industrial processes. In the 2001 Workshop on Good Practices in Policies and Measurers.

Blumstein C., Krieg B., Schipper L, York C. M., 1980, Overcoming social and institutional barriers to energy conservation. Energy 5:355-371 Caffal, C., 1995. Energy management in industry. Centre for the Analysis and Dissemination of Demonstrated Energy Technologies (CADDET). Analysis Series 17. Sittard, The Netherlands.

Brown, M.A., 2001, Market failures and barriers as a basis for clean energy policies. Energy Policy 29:1197-1207.

Chai,K-H., Yeo, C., 2012. Overcoming energy efficiency barriers through systems approach-A conceptual framework. Energy Policy 46:460-472.

Christoffersen, L.B., Larsen, A., Togeby, M., 2006. Empirical analysis of energy management in Danish industry. Journal of Cleaner Production;14(5):516-26.

Cooremans C., 2011, Investment in energy efficiency: Do the characteristics of investments matter?, ECEEE Summer Study, 6-11 June, 2011.

DeCanio S., 1993, Barriers within firms to energy efficient investments. Energy Policy 9:906-914.

DeCanio,S. 1998, The efficiency paradox: bureaucratic and organizational barriers to profitable energy-saving investments, Energy Policy26 (5): 441-454 
de Groot H, Verhoef E., Nijkamp P., 2001, Energy saving by firms: decision-making, barriers and policies. Energy Economics 23:717-740.

Gordic D., Babic M., Jovicic N., Sustersic V., Koncalovic D., Jelic D., 2010. Development of an energy management system - Case study of a Serbian car manufacturer. Energy conversion and management 51.2783-2790

EC (European Commission), 2006, Communication from the Commission. Ac-tion Plan for Energy Efficiency: Realizing the Potential. COM (2006) 545

EC (European Commission), 2011. Energy Efficiency Plan 2011. SEC(2011) 277 final.

Eichner, T., Pethig, R., Carbon leakage, the green paradox and perfect future markets, International Economic Review 52: 767-04

Fleiter T, Worrell E, Eichhammer W. (2011), Barriers to energy efficiency in industrial bottom-up energy demand models-A review. Renewable and Sustainable Energy Reviews 15: 3099-3111

Foss, N., 1997, The resource based perspective: as assessment and diagnosis of problems, Scand. J. Mgmt, Vol. 14, No. 3. pp. 133-149, 1998

Gordic D., Babic M., Jovicic N., Sustersic V., Koncalovic D., Jelic D., 2010. Development of an energy management system - Case study of a Serbian car manufacturer. Energy conversion and management 51.2783-2790

Gruber E., Brand M., 1991, Promoting energy conservation in small and medi-um-sized companies. Energy Policy 19:279-287

Hahn, R. W., Stavins, R.N., 1992, Economic incentives for Environmental Protection: Integration Theory and Practice, The American Economic Review 82 (2): 464-468

Hasanbeigi A, Menke C, du Pont P. (2010), Barriers to energy efficiency improvement and decisionmaking behavior in Thai industry. Energy Efficiency 3: 33-52.

Hirst E., Brown M. A., 1990, Closing the efficiency gap: barriers to the efficient use of energy. Resources, Conservation and Recycling 3 (4): 267-281

Jaffe, A.B., Stavins, R.N., 1994. The energy efficiency gap: what does it mean? Energy Policy 22 (10): 60-71.

John, C., 2004.Maximizing energy savings with enterprise energy management systems. IEEE power \& energy. 
Kraaijenbrink, J., Spender, J-C., Groen, A.J, The Resource-Based View: A Review and Assessment of Its Critiques, Journal of Management 2010 36: 349

Mckeiver C., Gadenne D., 2005, Environmental Management Systems in Small and Medium International Small Business Journal 23: 513-37

Ostertag, K., 1999, Transaction Costs of Raising Energy Efficiency. In: Pro-ceedings of the 2007 IEA international Workshop on Technologies to Reduce Greenhouse gas Emissions: EngineeringEconomic Analyses of Conserved Ener-gy and Carbon

Rohdin P., Thollander P., 2006, Barriers to and driving forces for energy effi-ciency in the nonenergy intensive manufacturing industry in Sweden. Energy 31:1836-44.

Rohdin P., Thollander P., Solding P., 2007, Barriers to and drivers for energy efficiency in the Swedish foundry industry. Energy Pol 35:672-77

Sanstad A., Howarth R., 1994, 'Normal' markets, market imperfections and en-ergy efficiency. Energy Policy 22: 811-818.

Sardianou E., 2008, Barriers to industrial energy efficiency investments in Greece. J Clean Prod $16: 1416-23$

Schleich J., 2004, Do energy audits help reduce barriers to energy efficiency? An empirical analysis for Germany. International Journal of Energy Technology and Policy 2:226-239.

Schleich J., Gruber E., 2008, Beyond case studies: Barriers to energy efficiency in commerce and the services sector. Energy Economics 30:449-464.

Sorrell S, Schleich J, Scott S, O’Malley E, Trace F, Boede E, Ostertag K, Radgen P (2000) Reducing Barriers to Energy Efficiency in Public and Private Organizations. SPRU's (Science and Technology Policy Research): http://www.sussex. ac.uk/Units/spru /publications/reports/ barriers/final.html. Accessed 8 October 2007

Sorrell, S., O’Malley, E., Schleich, J., Scott, S., 2004, The economics of energy efficiency barriers to cost-effective investment, Edward Elgar, Cheltenham

Stern P. C., Aronson E., (Eds), 1984, Energy Use: The Human Dimension. Freeman, New York

Stern P. C., 1992, What Psychology Knows About Energy Conservation. Amer-ican Psychologist 47:1224-1232

Swords B., Coyle E., Norton B., 2007. An enterprise energy-information system .Applied energy 85. 61- 69. 
Thollander P., Danestig M., Rohdin P., 2007, Energy policies for increased industrial energy efficiency: evaluation of a local energy programme for manufacturing SMEs. Energy Policy $35: 5774-83$.

Thollander, P., Ottosson, M., 2008. An energy efficient Swedish pulp and paper industry: exploring barriers to and driving forces for cost-effective energy efficiency investments. Energy Efficiency;1(1):21-34.

Thollander, P., Ottosson, M., 2010. Energy management practices in Swedish energy-intensive industries. Journal of Cleaner Production 18(12): 1125-1133

Thollander P., Rohdin P., Moshfegh B., 2012, On the formation of energy poli-cies towards 2020: challenges in the Swedish industrial and building sectors. En-ergy Policy (forthcoming).

Thollander, P., Solding P., Söderström, M., 2009. Energy Management in Industrial SMEs.

Proceedings of the 5th European conference on economics and management of energy in industry (ECEMEI-5), 2009: 1-9.

Trianni A., Cagno E., 2011. Dealing with barriers to energy efficiency and SMEs: Some empirical evidences. Energy 37 (1): 494-504.

Verdin, P. J. and Williamson, P. J. (1994) Core competences, competitive advantage and market analysis: forging the links. In Competence-Based Competition, eds G. Hamel and A. Heene. John Wiley, New York.

Waide P, Brunner C, 2011, Energy-Efficiency Policy Opportunities for Electric Motor-Driven Systems. IEA (International Energy Agency), Energy Efficiency, Paris.

Weber L., 1997, Some reflections on barriers to the efficient use of energy. En-ergy Policy 25:833835

York C. M., Blumstein C., Krieg B., Schipper L., 1978, Bibliography in institu-tional barriers to energy conservation. Lawrence Berkeley Laboratory and Univer-sity of California, Berkeley 